\title{
New anatomical information on arms and fins from exceptionally preserved Plesioteuthis (Coleoidea) from the Late Jurassic of Germany
}

\author{
Christian Klug $^{1} \cdot$ Dirk Fuchs $^{2}$ - Günter Schweigert ${ }^{3}$ - Martin Röper ${ }^{4}$ \\ Helmut Tischlinger ${ }^{5}$
}

Received: 26 February 2015 / Accepted: 26 June 2015 / Published online: 29 September 2015

(C) Akademie der Naturwissenschaften Schweiz (SCNAT) 2015

\begin{abstract}
Plesioteuthis is a coleoid rather well known from the classical Fossillagerstätten of southern Germany (Solnhofen-Eichstätt region, Nusplingen). Here, we present two new specimens that display unusually preserved cirri-bearing arms and two pairs of fins. Based on these specimens, we shortly discuss in how far arm arrangement in the fossils might reflect behaviour. Additionally, we revise the phylogenetic position of the Jurassic vampyromorphs.
\end{abstract}

Keywords Coleoidea $\cdot$ Fossillagerstätten $\cdot$ Late Jurassic · Anatomy $\cdot$ Phylogeny $\cdot$ Behaviour $\cdot$ Palaeoecology

Christian Klug

chklug@pim.uzh.ch

Dirk Fuchs

dfuchs@mail.sci.hokudai.ac.jp

Günter Schweigert

guenter.schweigert@smns-bw.de

Martin Röper

m.roeper@solnhofen.de

Helmut Tischlinger

htischlinger@online.de

1 Paläontologisches Institut und Museum, Universität Zürich, Karl Schmid-Strasse 4, 8006 Zurich, Switzerland

2 Earth and Planetary System Science, Department of Natural History Sciences, Hokkaido University, Sapporo, Japan

3 Staatliches Museum für Naturkunde, Rosenstein 1, 70191 Stuttgart, Germany

4 Museum Solnhofen, Bahnhofstr. 8, 91807 Solnhofen, Germany

5 Tannenweg 16, 85134 Stammham, Germany

\section{Introduction}

Lithographic limestone occurrences of southern Germany have yielded many important fossils that contributed valuable new anatomical information (e.g. Foth et al. 2014). This applies not only to vertebrates but also to invertebrates. As far as cephalopods are concerned, these Fossillagerstätten produced specimens preserving phosphatized and carbonized soft tissues such as arms, fins, gills, mantle remains, spermatophores, originally cartilaginous structures such as the head capsules, and formerly chitinous parts including arm hooks, beaks, radulas, and gladii (Quenstedt 1849, 1852; Naef 1922; Dietl and Schweigert 1999; Schweigert and Dietl 1999, 2001, 2008; Klug et al. 2005, 2010a, b, Fuchs et al. 2003; Keupp 2006; Fuchs 2006; Keupp et al. 2010; Donovan and Fuchs 2015). By far most of these organs have been observed in coleoid cephalopods and usually not in ectocochleate forms. Among the coleoids, Plesioteuthis belongs to the most common genera of coleoids that is found both in the Solnhofen-Eichstätt region (Bavaria) and in Nusplingen (Baden Württemberg). In these regions, exceptionally preserved specimens of Plesioteuthis have been discovered preserving arms, beaks, fins, gills, ink sac, mantle, and the stomach contents (Klinghardt 1932; Bandel and Leich 1986; Haas 2002; Keupp et al. 2010; Klug et al. 2010a, b; Schweigert and Dietl 2010). Therefore, the anatomy of this coleoid is reasonably well known compared to the very poor knowledge of the anatomy of other cephalopods such as contemporary ammonites. Besides Plesioteuthis, the anatomy of other genera of the Plesioteuthidae such as co-existing Senefelderiteuthis (Engeser and Keupp 1999; Fuchs et al. 2007b) and the Late Cretaceous genus Dorateuthis (Fuchs and Larson 2011a) are likewise well documented. Nevertheless, the phylogenetic position of the Plesioteuthidae (this shorter name is used for simplicity instead of Plesioteuthididae) is still disputed. While 
it has been suggested that plesioteuthids and other Mesozoic gladius-bearing coleoids (e.g. Trachyteuthis, Palaeololigo, Leptotheuthis, etc.) were stemgroup Decabrachia that just never preserved the fifth arm pair (e.g. Naef 1922; Jeletzky 1966; Young et al. 1998; Vecchione et al. 1999; Donovan and Strugnell 2010), others have interpreted this absence as one argument supporting an affinity to the Octobrachia (e.g. Bandel and Leich 1986; Haas 2002; Klug et al. 2005; Fuchs 2006; Fuchs et al. 2007a, b; Fuchs and Larson 2011a, b; Kröger et al. 2011; Donovan and Fuchs 2015). The latter seemed to be falsified by the gladius morphology which very much resembles the hard parts of Recent teuthid squids, although possibly only superficially. This shows that any additional anatomical detail may be of importance to test these alternative phylogenetic hypotheses.

Herein, we describe two unusually preserved specimens of the coleoid Plesioteuthis prisca (Rüppell 1829). We use the anatomical information to shortly revise the available hypotheses of the phylogenetic position of this genus.

Institutional abbreviations-Palaeontological Institute and Museum, University of Zurich, Switzerland (PIMUZ); Museum Solnhofen, Germany (BMMS).

\section{Material}

Two specimens are included in this study. Both belong to the most common non-belemnite coleoid species, Plesioteuthis prisca (Rüppell 1829). The first specimen (BMMS 617a) was found by Martin Röper (Solnhofen) in the Upper Kimmeridgian, Beckeri Zone, Ulmense Subzone (lower layers), rebouletianum Horizon (Torleite Formation) in the Rygol quarry (Fig. 1) in Painten (Bavaria). This occurrence of lithographic limestone became famous because in contrast to many other occurrences in the Solnhofen-Eichstätt region, fossils sometimes preserve carbonized structures. In this respect, Painten resembles the locality of Nusplingen (e.g. Klug et al. 2005, 2010a, b). The specimen we present here is nearly complete except the apical part of the gladius, the posterior mantle, and the fins. Both slab and counterslab are available.

It is exactly the posterior part-missing in the first specimen - that is nearly perfectly preserved in the second specimen (PIMUZ 31316). It belongs to the same species and was acquired from a private collection. The original label indicates "Malm zeta", i.e. Hybonotum Zone of the
Fig. 1 Map showing the two localities Painten and Eichstaett

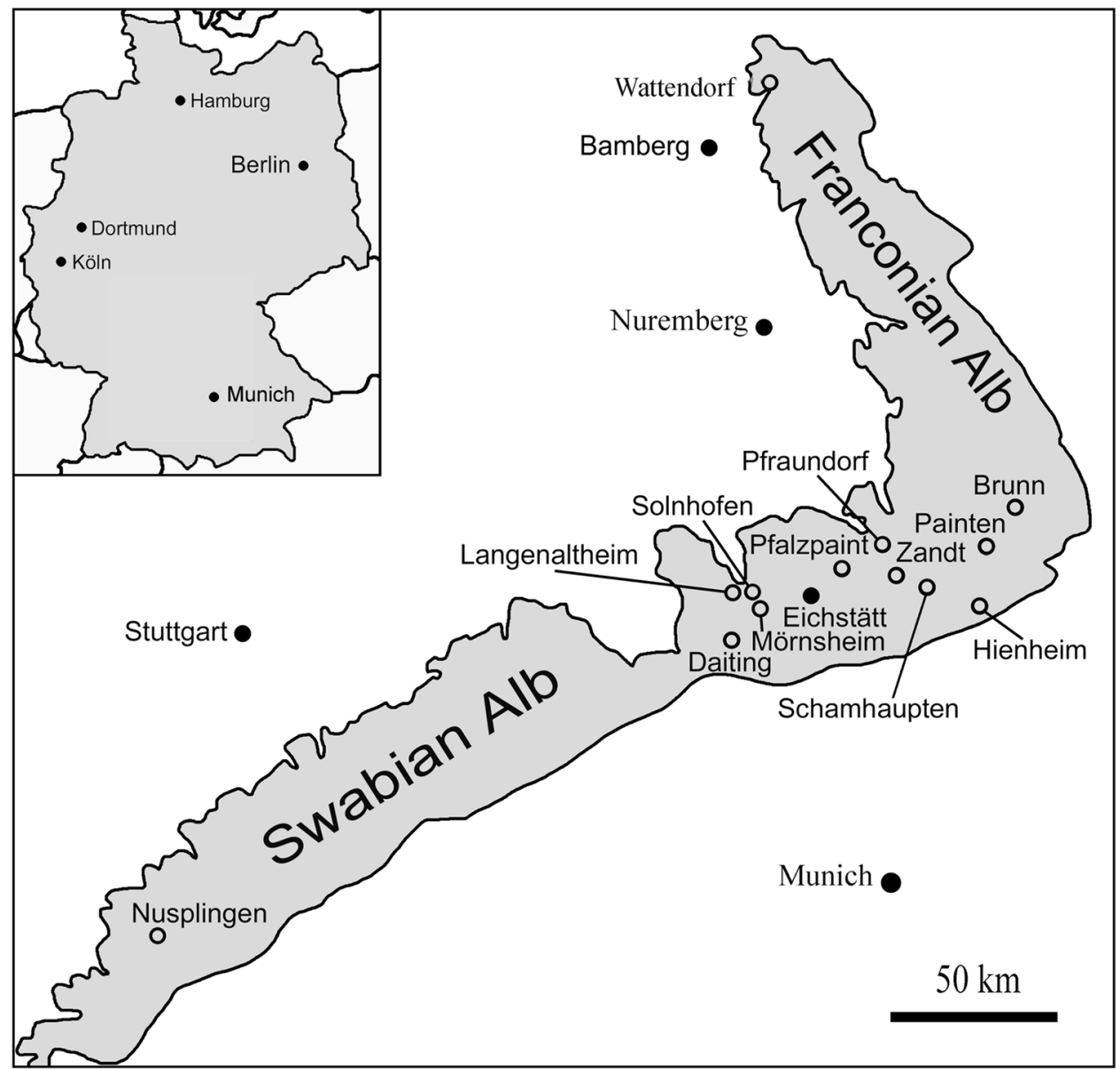


Tithonian. It was found at the locality Blumenberg near Eichstätt (Bavaria) where lithographic limestones of Tithonian age (Hybonotuum Zone) are exposed. This specimen preserves the complete gladius with most of the phosphatized mantle muscles and the first evidence of two pairs of fins in the Plesioteuthidae. a in

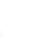

Fig. 2 Plesioteuthis prisca (Rüppell 1829), BMMS 617a, Beckeri Zone, Ulmense Subzone, rebouletianum Horizon, Rygol quarry, Painten (Bavaria, Germany). a Drawing of the specimen after the image in b with references to magnified parts of Fig. 3 and 4. b Photograph of the specimen 


\section{Descriptions}

\section{Specimen BMMS 617a}

Figures 2, 3, 4 .

General the fossil is about $25 \mathrm{~cm}$ long and seen in lateral aspect. It preserves the complete arm crown, parts of the head, gladius with mantle, and several internal organs which are more or less well discernible. The most posterior part is missing. The dimension of the missing part can be reconstructed by comparing this specimen with the second one (PIMUZ 31316). Both have about the same maximum gladius width (PIMUZ 31316: $19 \mathrm{~mm}$; BMMS 617a: ca. $18.5 \mathrm{~mm}$ ). The gladius in PIMUZ 31316 is $189 \mathrm{~mm}$ long. In BMMS $617 \mathrm{a}, 147 \mathrm{~mm}$ of the gladius is preserved. Thus, about $20 \mathrm{~mm}$ is missing (the part with the fins and the
Fig. 3 Plesioteuthis prisca (Rüppell 1829), BMMS 617a, Beckeri Zone, Ulmense Subzone, rebouletianum Horizon, Rygol quarry, Painten (Bavaria, Germany). a Drawing of the gill region after the image in $\mathbf{b}$. b Photograph of the gill region. c Drawing of the buccal mass after the image in d. d Photograph of the buccal mass
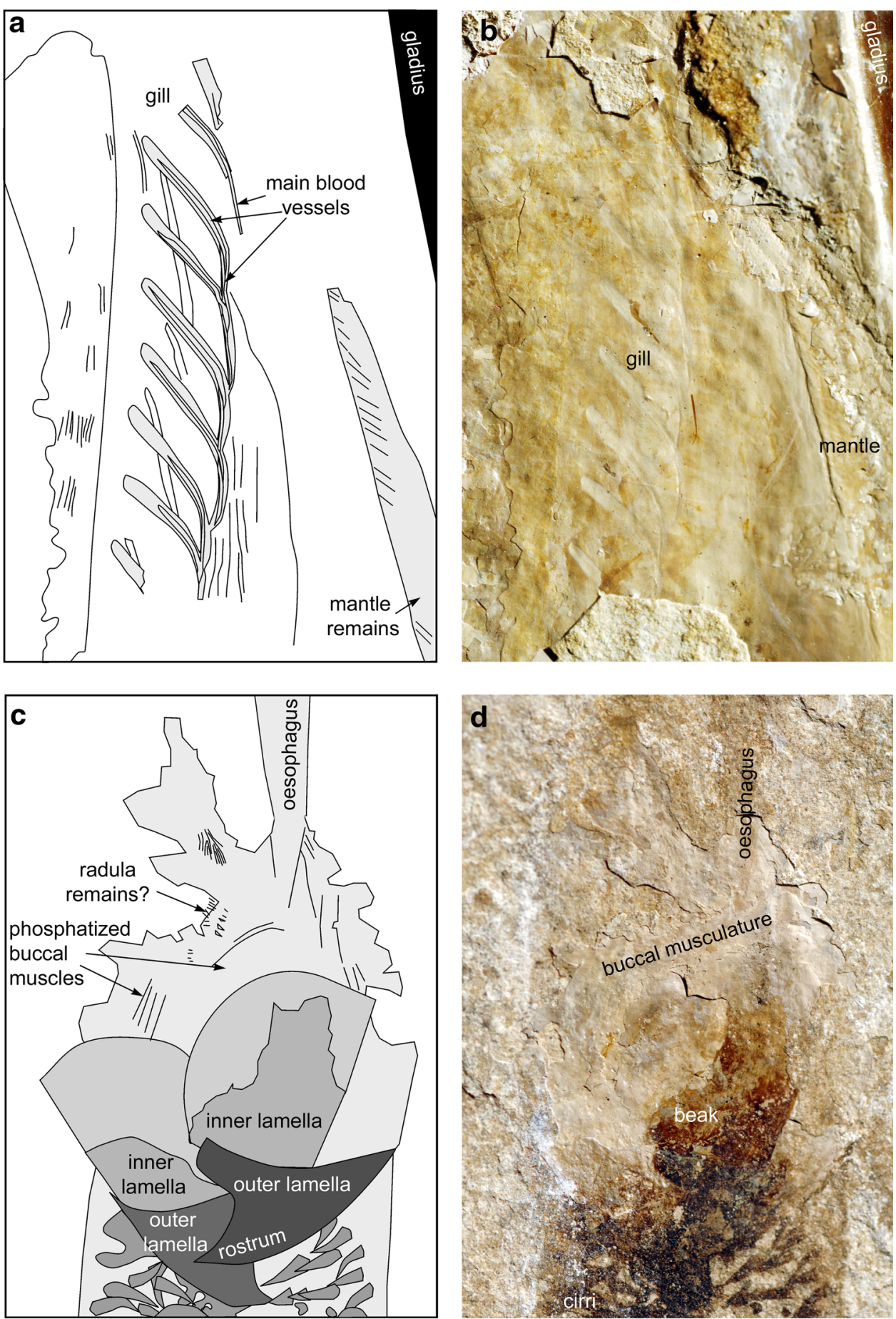

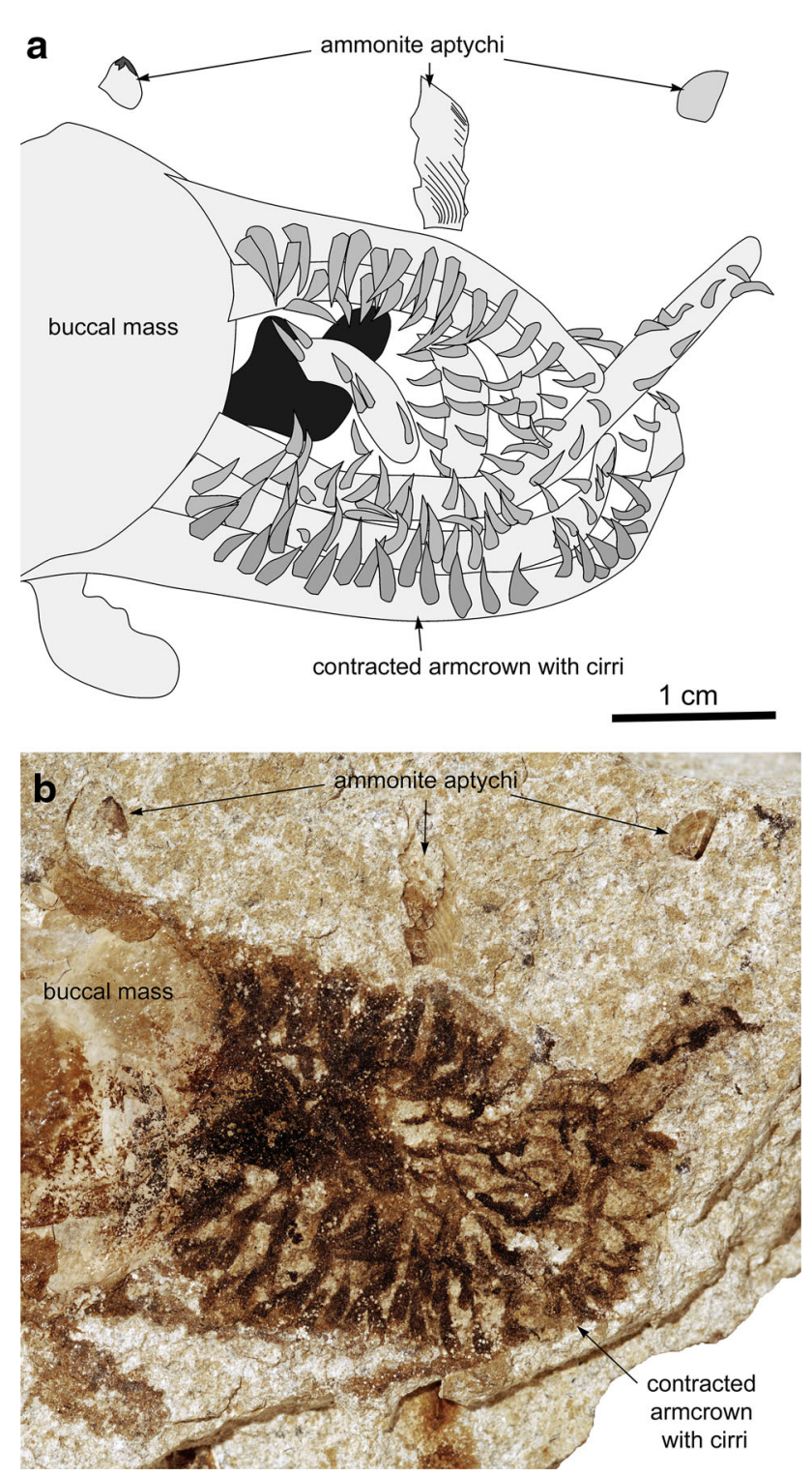

Fig. 4 Plesioteuthis prisca (Rüppell 1829), BMMS 617a, Beckeri Zone, Ulmense Subzone, rebouletianum Horizon, Rygol quarry, Painten (Bavaria, Germany). a Drawing of the arm crown after the image in b. b Photograph

conus; Fuchs et al. 2007b found a ratio gladius width/ length of 0.11-0.12). This specimen preserves soft parts either in phosphate (brownish to greyish) or in carbon (dark brown).

Arm crown the entire arm crown is about $30 \mathrm{~mm}$ long (Figs. 2, 3, 4). Superficially, it resembles an opened fig, because the cirri are excellently visible, pointing inwards from the inward curved arms. Both arms and cirri are carbonized. The thickness of the carbon layer of the cirri appears to be thicker since they are much darker than the rather faint traces of the arms. Distinct imprints of suckers were not seen. Cirri length varies from 2 to $5 \mathrm{~mm}$. The assignment of single cirri to arms is difficult to impossible in many cases; nevertheless, it appears like they were arranged in pairs at least locally (see the top arm in Fig. 4a). In the centre of the arm crown, a dark patch is visible which is almost $1 \mathrm{~cm}$ long and which has an irregular outline and coloration. It is not clear whether these are cirri, prey remains, or a combination of both. The question arises why the cirri are carbonized. Often, fossilized chitinous or melanin-bearing structures display such preservation. With our data, it cannot be decided, which is true. Further examinations have to be carried out.

Buccal mass the buccal mass is about $23 \mathrm{~mm}$ high in its flattened state and $20 \mathrm{~mm}$ long (Figs. 2, 3). It is subcircular and the buccal muscles appear to be phosphatized based on their greyish colour. However, under UV light, none of the structures preserved in the specimen were luminescent. In the centre of the buccal mass, both mandibles are preserved in situ. Based on their light to dark brownish colour, we conclude that both beaks are carbonized. The upper beak is about $15 \mathrm{~mm}$ long (the rostrum is part of the dark undifferentiated mass that sticks between the arms). It is reasonably well preserved and displays the morphology described earlier by Klug et al. (2005, 2010a). The lower beak is much less well preserved. Thus, nothing can be written here on its morphology. On the posteroventral part of the phosphatized buccal mass, a regular pattern is visible; it is reminiscent in size of the single marks and its position of a radula, but morphological detail is missing that could corroborate this interpretation.

Gladius the anterior $15 \mathrm{~cm}$ of the $18-20 \mathrm{~cm}$ long gladius is preserved (see discussion above). Except the typical lateral keels, the anterior portion of the median field is very poorly preserved and in the middle, it was bent, possibly during compaction of the sediment or during necrolysis, but an injury can also not be ruled out. The gladius shows the characteristic morphologic features of the species (Fig. 2).

Mantle nearly in the middle of the gladius, a broad patch of phosphatized tissue is preserved (Fig. 2). It is partially transversely striated, partially covers the gladius and thus can be confidently interpreted as mantle remains.

Ink sac and duct both ink sac and duct are well visible (Fig. 2). The ink remains are eroded but the characteristic brownish to black colour of the ink remains provide a good support for the interpretation as ink sac and duct. The 3Dpreserved ink sac is $14 \mathrm{~mm}$ long and $10 \mathrm{~mm}$ wide. The ink duct is about $80 \mathrm{~mm}$ long and $4 \mathrm{~mm}$ wide. Where it leads into the rectum/intestine, the ink filled tract makes a slight kink of about 20 degrees. The ink filled part of the rectum/ intestine is about $30 \mathrm{~mm}$ long. At the end of the supposed rectum/intestine, it appears like ink was spilled at or shortly after death because an irregular patch of ink of nearly $30 \mathrm{~mm}$ length follows outside the supposed rectum/ intestine. 
Gills parts of the gills are excellently preserved while other parts can be seen only vaguely. The best preserved part consists of ca. $5 \mathrm{~mm}$ long lanceolate filaments (Fig. 3a, b). Each filament has a rounded end. The other end narrows and bends anteriorly. Each of the filaments contains a very narrow elongate structure which appears like a blood vessel. Each of these supposed afferent blood vessels gives rise to the next branch at the base of its filament. This one gill branch preserves 9 filaments but there were likely more. The other branch is evident only from a neighboured pattern of regular breaks in the phosphate layers, probably reflecting the presence of filaments below. Thus, both gills are apparently preserved.

Digestive tract the oesophagus is preserved in phosphate directly posterior to the buccal mass. It can be traced over nearly $30 \mathrm{~mm}$ posterior of the buccal mass and is up to $4 \mathrm{~mm}$ wide. Additionally, behind the ink sac, a yellowish to brownish patch of $28 \mathrm{~mm}$ length and $20 \mathrm{~mm}$ width is visible. Its outline is fading and within this patch, the surface is somewhat rugged. From its position and dimension, we suggest that this might be the stomach, which is perhaps still covered by a thin layer of a different tissue. Over about $45 \mathrm{~mm}$, a stripe of the same colour as the supposed stomach runs parallel to the ink duct, tapering anteriorly. We suggest that this is part of the intestine.

Other organs there are several longitudinal structures around the gills which lack distinct features to permit a conclusion on what they were. According to their structure and position, they could be the funnel retractor muscles, digestive glands, or parts of the blood circulatory system.

Comparison the co-existing Senefelderiteuthis tricarinata lacks the median keel and has longer arms. We thus assign this specimen to Plesioteuthis prisca (Rüppell 1829).

\section{Specimen PIMUZ 31316}

General this specimen is $189 \mathrm{~mm}$ long and up to $39 \mathrm{~mm}$ wide (Fig. 5). It is embedded ventrodorsally, showing the body with the mantle, ink sac, gladius and fins. Since the
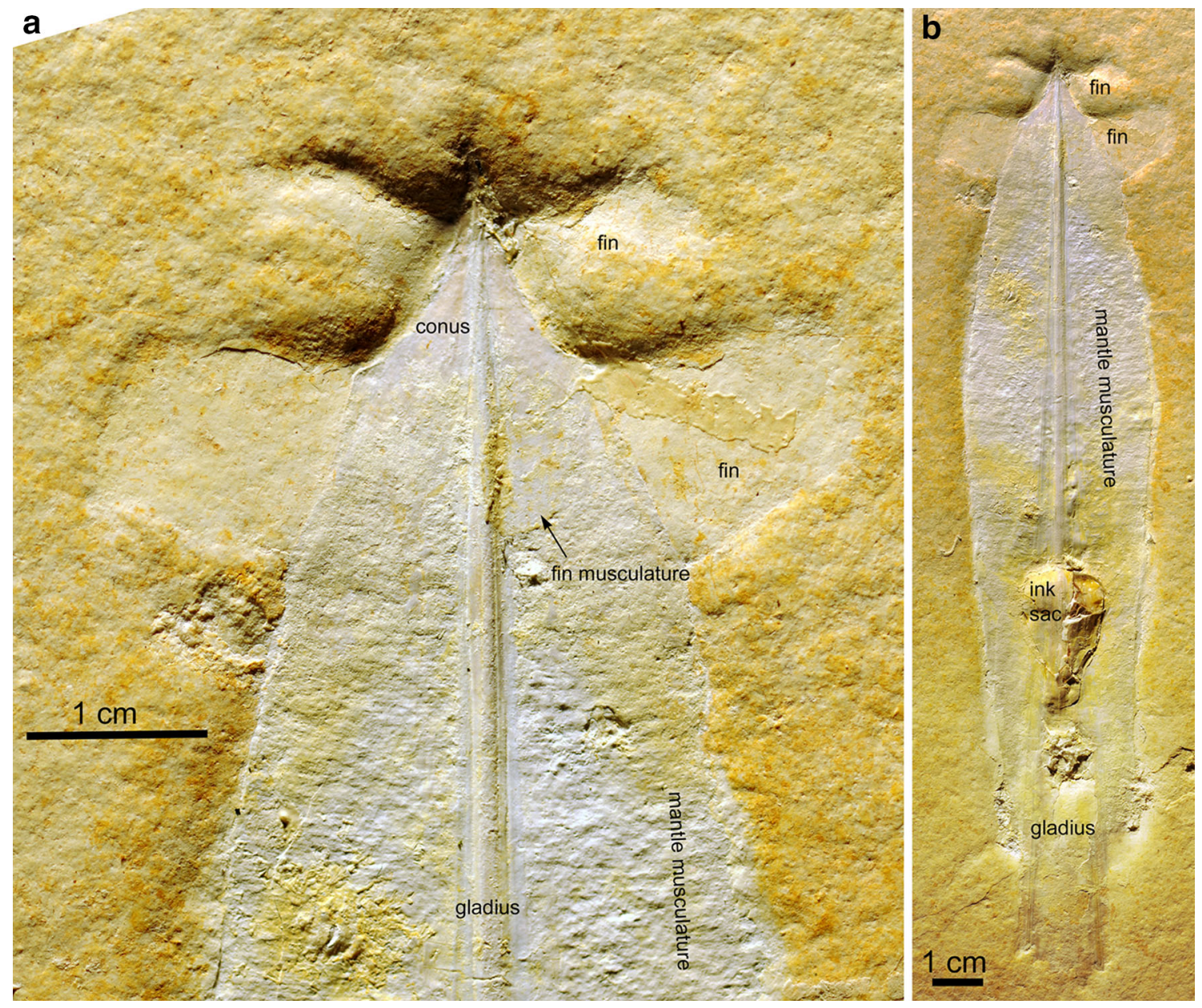

Fig. 5 Plesioteuthis prisca (Rüppell 1829), PIMUZ 31316, Solnhofen Lithographic Limestone, Hybonotum Zone, Early Tithonian, Blumenberg near Eichstätt (Bavaria, Germany). Note the perfectly visible fins. a Detail of $\mathbf{b}$. b Complete specimen 
gladius overlies the ink sac, the specimen is seen from its dorsal side.

Gladius the gladius is quite well preserved, $189 \mathrm{~mm}$ long and $19 \mathrm{~mm}$ wide at its anterior end. The flattened conus is visible at the posterior end. In its flattened state, it measures $14 \mathrm{~mm}$ in width and $10 \mathrm{~mm}$ in length. There is no evidence of a rostrum-like investment around the conus.

Mantle the mantle is almost completely preserved and strongly phosphatized. It shows the characteristic transverse banding from the transverse arrangement of the ring muscle fibres. The muscle fibres appear to insert at the margin of the median field of the gladius.

Ink sac and duct the ink sac is about $17 \mathrm{~mm}$ wide and $30 \mathrm{~mm}$ long. It preserves only the most posterior part of the ink duct. It is still covered by phosphatic remains of mantle and gladius. Thus, the ink colour is hardly visible.

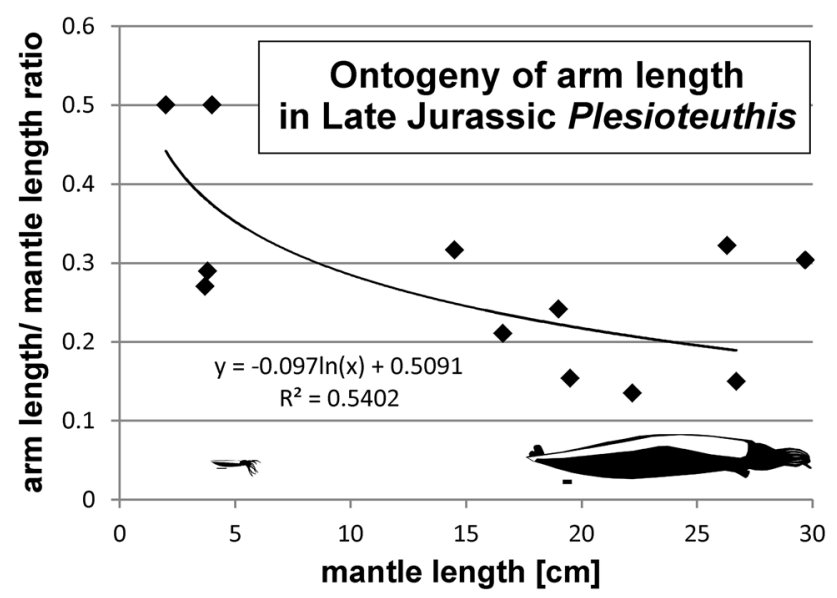

Fig. 6 Arm lengths of Plesioteuthis prisca (Rüppell 1829) of various growth stages. Note that there appears to be a reduction of relative arm length through ontogeny. The two silhouettes are drawn to scale with a centimetre scale bar below (see also Fig. 7)
Fins this specimen is to our best knowledge the second that exhibits two pairs of small lobate fins (Leich 1968: p. 50, 51). All four of the small lobate fins are completely preserved. The anterior pair measures about $15 \mathrm{~mm}$ from the mantle outward and is $13-16 \mathrm{~mm}$ wide at the base where it crosses the mantle. The posterior fins are smaller and have a length of $10-11 \mathrm{~mm}$ and a width of 7-8 $\mathrm{mm}$. The posterior fins appear to be attached along the posterior part of the conus. Furthermore, one of the fins preserves remains of the tissues that anchored the fin to the gladius. This is evident from a very fine striation which is oriented at an angle of about 10 degrees to the mantle muscle fibres. The subterminal fin pair previously described by various authors (e.g. Naef 1922; Leich 1968; Fuchs et al. 2007b; Fuchs 2006) probably corresponds to the anterior pair.

\section{Arm posture, length, and behaviour}

We compared the arm length of the main specimen (BMMS 617a) to those of other specimens (Tab. 1) published both in print (Frickhinger 1994, 1999) and online. We found that the ratio of arm length to the mantle length varies between 0.13 and 0.5 with a normal value of about $0.2(<0.2$ indicates strongly contracted arms); BMMS 617a displays a very low arm to mantle length ratio. This leads to the question whether this particular arm posture is potentially linked with perimortal processes (e.g. necrolytic processes, agonal muscle contractions).

In Recent coleoids, more than ten different arm postures have been described (e.g. Mather et al. 2010; Barbosa et al. 2012) which were associated with different behaviour. Fossils of Plesioteuthis also display a great variety of arm postures, some of which (Fig. 6) resemble those illustrated
Table 1 Some measurements of some Late Jurassic specimens of Plesioteuthis (possibly, some of the smaller specimens belong to other plesioteuthid genera such as Senefelderiteuthis) from southern Germany

\begin{tabular}{llllll}
\hline Specimen & $\begin{array}{l}\text { Length } \\
\text { L }\end{array}$ & $\begin{array}{l}\text { Arm length } \\
\mathrm{a}\end{array}$ & $\begin{array}{l}\text { Mantle length } \\
\text { Ml }\end{array}$ & a/L & a/Ml \\
\hline Frickhinger (1994): Fig. 140 Solnhofen & 26 & 4.59 & 14.5 & 0.176538 & 0.316552 \\
BMMS 617a, Painten & 28 & 3 & 19.5 & 0.107143 & 0.153846 \\
Wintershof & 7.5 & 2 & 4 & $\mathbf{0 . 2 6 6 6 6 7}$ & $\mathbf{0 . 5}$ \\
Slg. Rüdel, Eichstätt & 36 & 8.471 & 26.3 & 0.235306 & 0.322091 \\
Solnhofen & 27 & 3.5 & 16.6 & 0.12963 & 0.210843 \\
Slg. Starke, Blumenberg & 6 & 1.1 & 3.8 & 0.183333 & 0.289474 \\
Slg. Starke, Blumenberg 2 & 36 & 4 & 26.7 & 0.111111 & 0.149813 \\
Solnhofen & 28.3 & 4.59 & 19 & 0.162191 & 0.241579 \\
Frickhinger (1999): Fig. 45 Eichstätt & 6 & 1 & 3.7 & 0.166667 & 0.27027 \\
Frickhinger (1999): Fig. 43 Eichstätt & 29 & 3 & 22.2 & $\mathbf{0 . 1 0 3 4 4 8}$ & $\mathbf{0 . 1 3 5 1 3 5}$ \\
Slg. Starke, Blumenberg & 5.5 & 1 & 2 & 0.181818 & $\mathbf{0 . 5}$ \\
\hline After specims & & & & &
\end{tabular}

After specimens published in the literature and the internet. Extreme values in bold face 

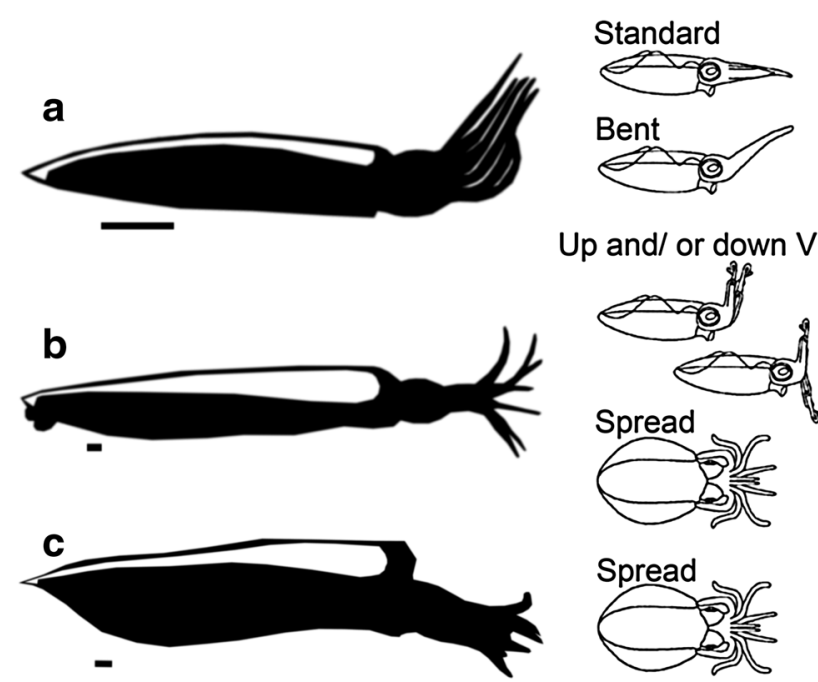

Up and/ or down V
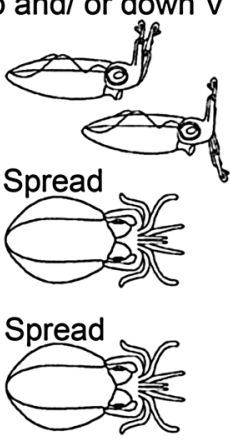

d
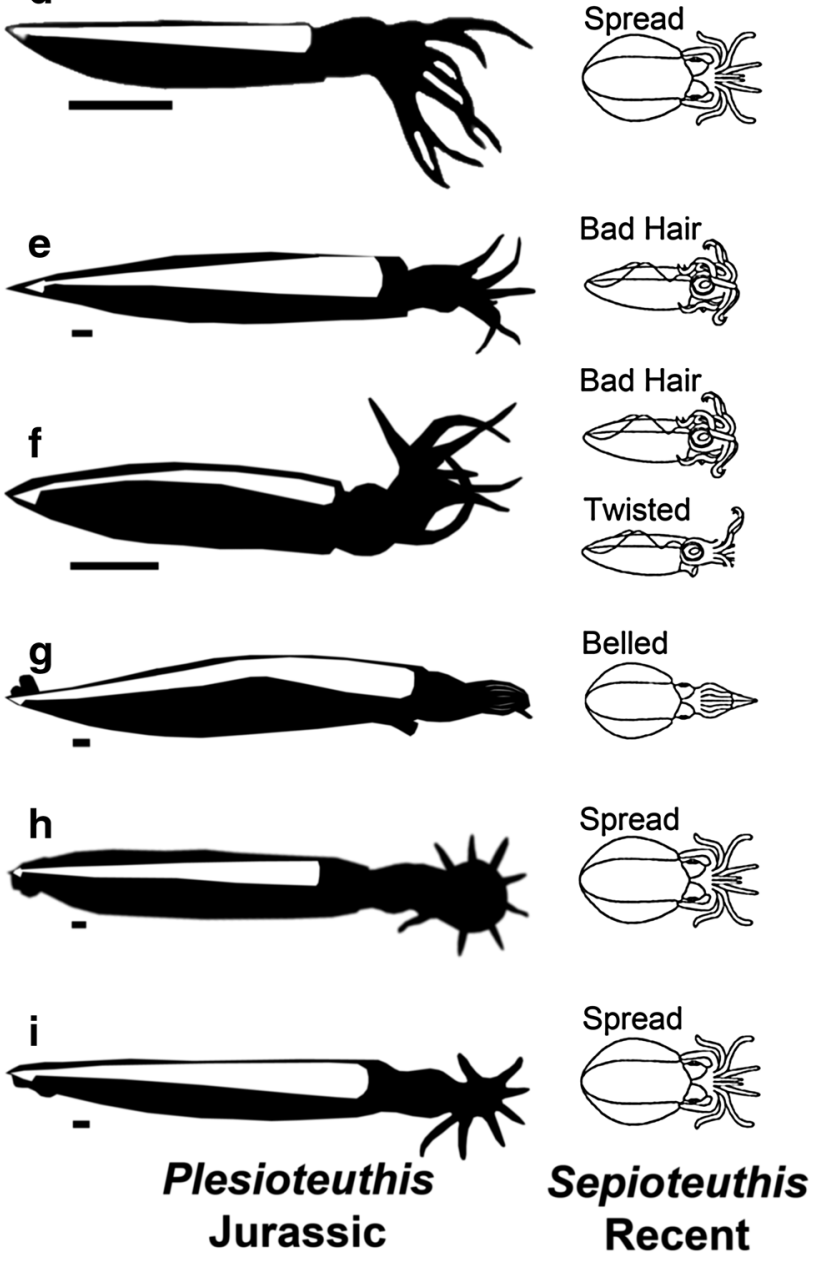

by Mather et al. (2010). Logically, it is impossible to discriminate between fossilized behaviour and postures achieved through taphonomic processes including current alignment or postmortem physiological processes leading to contraction or relaxation of musculature. Nevertheless,
४Fig. 7 Taphonomic arm postures of Plesioteuthis prisca (Rüppell 1829) compared to syn vivo arm postures of Sepioteuthis sepioidea reproduced from Mather et al. (2010). Note that this comparison does not implicate that the fossils show fossilized behaviour; it rather shows variation in contraction and extension or arms as well as how they could bend. Left: Outlines of fossils in black (white outline of gladius); right sketches from Mather et al. (2010) with the respective name of the posture. Scale bars $1 \mathrm{~cm}$. a Hybonotum Zone, Wintershof, Germany, after http://www.solnhofen-fossilienatlas.de/ fossil.php?fossilid=2350. b Hybonotum Zone, Eichstätt, Germany, after http://www.solnhofen-fossilienatlas.de/fossil.php?fossilid=777. c Eichstätt, stored in the Jura-Museum, after Frickhinger (1999: Fig. 43). d Hybonotum Zone, Blumenberg, Germany, after http:// www.solnhofen-fossilienatlas.de/fossil.php?fossilid=2115. e Tithonian, Solnhofen, Germany, stored in Teyler's Museum Haarlem, after Frickhinger (1994: Fig. 140). f Tithonian, Eichstätt, Germany, coll. Graupner (Planegg), after Frickhinger (1999: Fig. 45). g BMMS 617a, Beckeri Zone, Painten (Bavaria, Germany). h Hybonotum Zone, Eichstätt, Germany, after http://www.solnhofen-fossilienatlas.de/fos sil.php?fossilid=1058. i coll. C. Takken, Switzerland

the fossilized arm postures inform us about the possible arm movements and postures as well as different states of contraction or extension. It was suggested that hypersaline conditions (Schäfer 1962, 1972; Seilacher et al. 1985; Wellnhofer 1991; Viohl 1994) might have led to osmotic desiccation, thus causing changes in muscle length. This hypothesis was refuted by Reisdorf and Wuttke (2012), because according to these authors, there appears to be no evidence for hypersaline conditions in the time and region under consideration (there might be diverging opinions, however: Keupp 1977a, b; Barthel 1978). Also, the same type of deformations of the body can occur in waters of normal salinity, while carcasses do not necessarily show the deformations suggested to have formed in hypersaline waters (Reisdorf and Wuttke 2012).

Our example, specimen BMMS 617a, shows how strongly the arms could be contracted. Arm length in relation to the mantle varies between about 10 and $50 \%$, which is quite substantial. This is not surprising, however, since Recent coleoid arms also show great degrees of flexibility and syn vivo arm length variation. The arm posture documented in BMMS 617a appears quite peculiar. In Mather et al. (2010), a superficially similar posture was termed "belled". Superficially, this retracted posture with the inward curved arms and protected cirri reminds of a protective posture. The fact that some ink was expelled around the moment of death points at the possibility that short before its death, the animal might have experienced distress, potentially caused by a predator or else.

As far as arm length is concerned, we measured arm lengths in relation to the animal's mantle length in ten specimens (Table 1). Although the specimen number is quite low and in some cases the assignment to Plesioteuthis somewhat uncertain, it appears like the arm length in 
relation to mantle length was reduced during ontogeny (Fig. 7). More specimens should be measured to test this hypothesis.

\section{Four versus two fins}

There is an ongoing discussion on the importance of the presence of four fins in vampyromorphs (Pickford 1949, 1950). It has been shown for Trachyteuthis and Glyphiteuthis before (Donovan et al. 2003; Fuchs et al. 2007a; Fuchs and Schultze 2008; Fuchs and Larson, 2011b) and a doubtful illustration shows the possibility of the presence of four fins in Plesioteuthis (Barthel 1978). In that context, it has to be pointed out that in Vampyroteuthis, four fins are present only temporarily in juvenile specimens (Pickford 1949, 1950). Trachyteuthis potentially had four fins throughout its life since these fins can be seen in rather large specimens (gladius length $300 \mathrm{~mm}$; PIMUZ 17197). The same might apply to Plesioteuthis, since PIMUZ 31316 is also rather large already and still has the four fins. However, the fins might still be temporary since most other plesioteuthids are known to have only two fins and it appears that the two fin pairs are inserted differently. The anterior pair of fins is well attached to the conus, while the posterior pairs appear to be separated by a constriction. In any case, more specimens of other ontogenetic stages are needed to corroborate of falsifying the hypothesis that the four fin-stage is temporary (as in Vampyroteuthis) or persistent.

\section{Are the plesioteuthids decabrachians or octobrachians?}

At least superficially, the non-belemnitoid Coleoidea of the Jurassic appear like today's teuthids because of their similarities in gladius morphology (the gladius of Palaeololigo looks like Chtenopteryx, Plesioteuthis like Ommastrephes). Accordingly, the so-called fossil teuthids (Engeser 1988; Engeser and Bandel 1988) of the Jurassic were considered stemgroup decabrachians (Fig. 8a). Additionally, it was argued that the decabrachian ventrolateral pair of tentacles was missing for taphonomic reasons (Naef 1922; Vecchione et al. 1999; Donovan and Strugnell 2010). In the past years, however, the number of characters pointing at a strong affinity to octobrachians was revealed by exceptionally preserved fossils: two fin pairs in Trachyteuthis and now in Plesioteuthis (Figs. 5, 8), cirrate arms (Figs. 2, 3), 8 arms, no tentacles, uniserial suckers without toothed sucker rings, etc. (for further arguments, see Donovan and Fuchs (in press); Fuchs (in revision)). The material presented herein strongly supports the octobrachian affinities of the genus

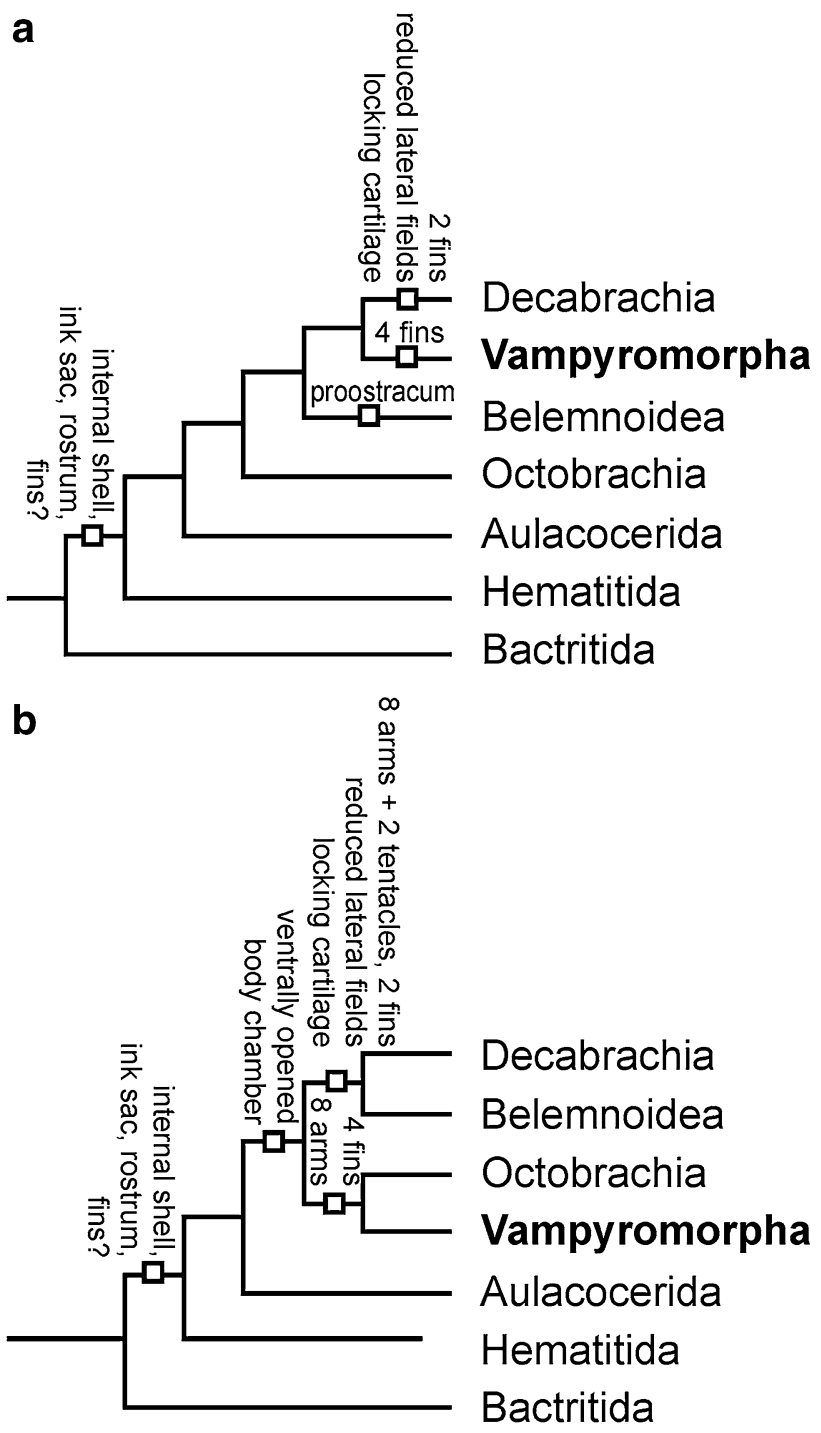

Fig. 8 Two alternative phylogenetic hypotheses of the relationships between some important coleoid clades. We reject hypothesis (a) and prefer hypothesis (b) according to our new anatomical information

Plesioteuthis with its two pairs of fins and its distinctly cirrate arms. Gill morphology did not provide new information to test the main phylogenetic hypotheses. Nevertheless, we state that the character states found in the material presented here confirm the hypotheses that Plesioteuthis is a stemgroup octobrachian (vampyropod; Figs. 8b, 9).

\section{Conclusions}

We present two new specimens of Plesioteuthis prisca (Rüppell 1829) from the Late Jurassic of Bavaria Germany. Specimen BMMS 617a displays much of its soft parts. They are either preserved in phosphate or carbon. The most interesting aspect is the arm crown. In this specimen, the 
Fig. 9 Reconstruction of Plesioteuthis prisca (Rüppell, 1829) after the new specimens. a lateral view, arms in "belled" position. b dorsal view, arms in "spread" position
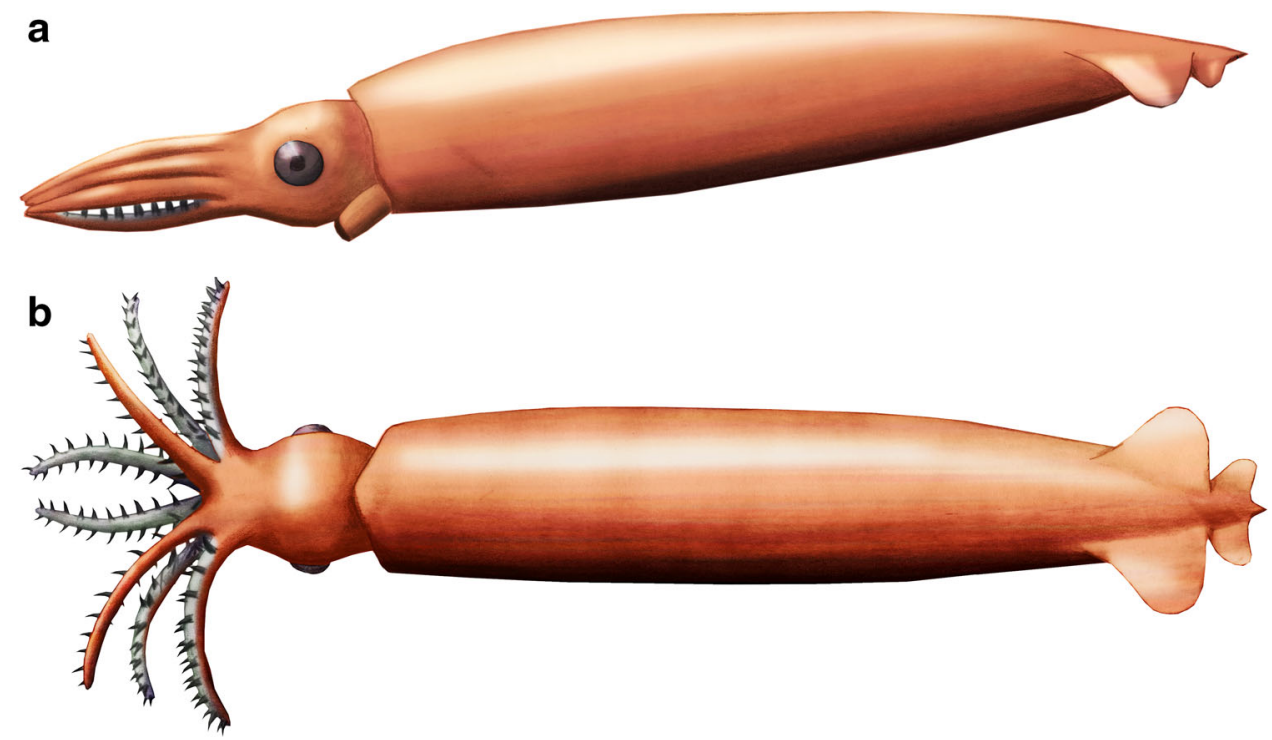

arms were strongly contracted near death and bent inward with the long, strongly carbonized cirri being nearly radially arranged. In combination with the fact that the ink duct is full of ink and some ink was spilled close to death, we suggest that both phenomena might reflect severe distress shortly before the animal's death. It is unknown how this animal's life ended.

The second specimen lacks head and arms. Nevertheless, it nearly perfectly preserves the phosphatized mantle musculature and the four fins. The gladius is also well preserved, showing details of the conus. These characters support the octobrachian affinity of the genus Plesioteuthis.

Acknowledgments Achim Reisdorf (Basel) discussed the taphonomy and perimortal processes that potentially affected dead coleoids with us. His input is greatly acknowledged. Chris Takken (Fällanden) kindly puts images of a specimen in his possession at our disposal. We greatly appreciate the help of two anonymous reviewers. Daniel Fauser (Aalen) provided the Plesioteuthis with fins.

\section{References}

Bandel, K., \& Leich, H. (1986). Jurassic Vampyromorpha (dibranchiate cephalopods). Neues Jahrbuch für Geologie und Paläontologie Monatshefte, 1986, 129-148.

Barbosa, A., Allen, J. J., Mäthger, L. M., \& Hanlon, R. T. (2012). Cuttlefish use visual cues to determine arm postures for camouflage. Proceedings of the Royal Society London B, 279, 84-90. doi:10.1098/rspb.2011.0196.

Barthel, K. W. (1978). Solnhofen. Ein Blick in die Erdgeschichte. Ott: Thun, p 393.

Dietl, G., \& Schweigert, G. (1999). Ein Nautilus mit in situ liegendem, vollständigem Kieferapparat aus dem Nusplinger Plattenkalk (Oberjura, SWDeutschland). Neues Jahrbuch für Geologie und Paläontologie Abhandlungen, 211, 75-87.

Donovan, D. T., Doguzhaeva, L., \& Mutvei, H. (2003). Two pairs of fins in the Late Jurassic Coleoid Trachyteuthis from southern Germany. Berliner paläobiologische Abhandlungen, 3, 91-99.
Donovan, D. T. \& Fuchs, D. (in press). Part M, Chapter 10: Fossilized soft tissues in Coleoidea. Treatise Online.

Donovan, D. T., \& Strugnell, J. (2010). A redescription of the fossil coleoid cephalopod genus Palaeololigo Naef, 1921 and its relationship to recent squids. Journal of Natural History, 44, $1475-1492$.

Engeser, T. (1988). Vampyromorpha ("Fossile Teuthiden"). In F. Westphal (Ed.), Fossilium Catalogus. I: Animalia: Pars 130 (p. 167). Amsterdam: Kugler Publications.

Engeser, T. \& Bandel, K. (1988). Phylogenetic classification of coleoid cephalopods. In J. Wiedmann \& J. Kullmann (Eds.), Cephalopods. Present and past (pp. 105-115). Schweizerbart: Stuttgart.

Engeser, T., \& Keupp, H. (1999). Zwei neue vampyromorphe Tintenfische (Coleoidea, Cephalopoda) aus dem oberjurassischen Solnhofener Plattenkalk von Eichstätt. Archaeopteryx, 17, 21-32.

Foth, C., Tischlinger, H., \& Rauhut, O. W. M. (2014). New specimen of Archaeopteryx provides insights into the evolution of pennaceous feathers. Nature, 511(7507), 79. doi:10.1038/ nature 13467.

Frickhinger, K. A. (1994). Die Fossilien von Solnhofen: Dokumentation der aus den Plattenkalken bekannten Tiere und Pflanzen (The fossils of Solnhofen) (p. 336). Goldschneck: Korb.

Frickhinger, K. A. (1999). Die Fossilien von Solnhofen, 2 (p. 190). Korb: Goldschneck.

Fuchs, D. (2006). Fossil erhaltungsfähige Merkmalskomplexe der Coleoidea (Cephalopoda) und ihre phylogenetische Bedeutung. Berliner Paläobiologische Abhandlungen, 8, 1-122.

Fuchs, D. (in revision). Part M, Chapter 21G: Systematics of fossil Octobrachia. Treatise Online.

Fuchs, D., Engeser, T., \& Keupp, H. (2007a). Gladius shape variation in the genus Trachyteuthis Meyer 1846 (Cephalopoda: Coleoidea) from the Late Jurassic Plattenkalks of Nusplingen (Kimmeridgian) and Solnhofen (Tithonian). Acta Palaeontologica Polonica, 52, 575-589.

Fuchs, D., Keupp, H., \& Engeser, T. (2003). New records of soft parts of Muensterella scutellaris MUENSTER, 1842 (Coleoidea) from the Late Jurassic Plattenkalks of Eichstätt and their significance for octobrachian relationships. Berliner Paläobiologische Abhandlungen, 3, 101-111.

Fuchs, D., Klinghammer, A., \& Keupp, H. (2007b). Taxonomy, morphology and phylogeny of plesioteuthidid coleoids from the 
Upper Jurassic (Tithonian) Plattenkalks of Solnhofen. Neues Jahrbuch für Geologie und Paläontologie Abhandlungen, 245, 239-252.

Fuchs, D., \& Larson, N. L. (2011a). Diversity, morphology, and phylogeny of coleoid cephalopods from the Upper Cretaceous Plattenkalks of Lebanon-Part I: Prototeuthidina. Journal of Paleontology, 85, 234-249.

Fuchs, D., \& Larson, N. L. (2011b). Diversity, morphology, and phylogeny of coleoid cephalopods from the Upper Cretaceous Plattenkalks of Lebanon-Part I: Teudopseina. Journal of Paleontology, 85, 815-834.

Fuchs, D., \& Schultze, H.-P. (2008). Trachyteuthis covacevichi n. sp., a Late Jurassic Palaeopacific coleoid cephalopod. Fossil Record, $11,39-49$.

Haas, W. (2002). The evolutionary history of the eight-armed Coleoidea. Abhandlungen der Geologischen Bundesanstalt, 57, 341-351.

Jeletzky, J. A. (1966). Comparative morphology, phylogeny and classification of fossil Coleoidea. Paleontological Contributions, University of Kansas, Mollusca, 7, 1-166.

Keupp, H. (1977a). Der Solnhofener Plattenkalk - ein BlaugrünalgenLaminit. Paläontologische Zeitschrift, 51, 102-116.

Keupp, H. (1977b). Ultrafazies und Genese der Solnhofener Plattenkalke (Oberer Malm, Südliche Frankenalb). Abhandlungen der Naturhistorischen Gesellschaft Nürnberg, 37, 1-128.

Keupp, H. (2006). Ein neuer Fall von Kiefer- und Kiemenerhaltung bei einem juvenilen Plesioteuthis prisca (Coleoidea) aus dem Solnhofener Plattenkalk. Leitfossil, pp. 1-6.

Keupp, H., Engeser, T., Fuchs, D., \& Haeckel, W. (2010). Ein Trachyteuthis hastiformis (Cephalopoda, Coleoidea) mit Spermatophoren aus dem Ober-Kimmeridgium von Painten (Ostbayern). Archaeopteryx, 28, 23-30.

Klinghardt, F. (1932). Über den methodischen Nachweis der Eingeweide bei fossilen Tintenfischen. Palaeontologische Zeitschrift, 14, 160-164.

Klug, C., Schweigert, G. \& Dietl, G. (2010a). A new Plesioteuthis with beak from the Kimmeridgian of Nusplingen (Germany). In D. Fuchs (Ed.), Proceedings of the Third International Coleoid Symposium. Ferrantia, 59, 73-77, Luxembourg.

Klug, C., Schweigert, G., Dietl, G., \& Fuchs, D. (2005). Coleoid beaks from the Nusplingen Lithographic Limestone (Late Kimmeridgian, SW Germany). Lethaia, 38, 173-192.

Klug, C., Schweigert, G., Dietl, G. \& Fuchs, D. (2010b). First record of a belemnite preserved with beaks, arms and ink sac from the Nusplingen Lithographic Limestone (Kimmeridgian, SW Germany). Lethaia, 43: 445-456, Oslo.

Kröger, B., Vinther, J. \& Fuchs, D. (2011). Cephalopod origin and evolution: A congruent picture emerging from fossils, development and molecules. Bioessays. doi:10.1002/bies.201100001.

Leich, H. (1968). Nach Millionen Jahren ans Licht. Versteinerungen der Jurazeit (p. 164). Ott, Thun, München.

Mather, J. A., Griebel, U., \& Byrne, R. A. (2010). Squid dances: an ethogram of postures and actions of Sepioteuthis sepioidea squid with a muscular hydrostatic system. Marine and Freshwater Behaviour and Physiology, 43(1), 45-61. doi:10.1080/ 10236241003660771.

Naef, A. (1922). Die fossilen Tintenfische (p. 322). Gustav Fischer: Jena.

Pickford, G. E. (1949). Vampyroteuthis infernalis Chun-an archaic dibranchiate cephalopod. II. External anatomy. Dana Report, 32, $1-33$.
Pickford, G. E. (1950). The Vampyromorpha (Cephalopoda) of the Bermuda Oceanographic Expeditions. Zoologica (Scientific Contributions of the New York Zoological Society), 35, 87-95.

Quenstedt, F. A. (1849). Petrefactenkunde Deutschlands. Erster Band: Die Cephalopoden. -Abt. 1 (p. 581). Fues: Leipzig.

Quenstedt, F. A. (1852). Handbuch der Petrefactenkunde (p. 792). Laupp: Tübingen.

Reisdorf, A. G., \& Wuttke, M. (2012). Re-evaluating Moodie's Opisthotonic-Posture Hypothesis in Fossil Vertebrates Part I: Reptiles - the taphonomy of the bipedal dinosaurs Compsognathus longipes and Juravenator starki from the Solnhofen Archipelago (Jurassic, Germany). Palaeobiodiversity and Palaeoenvironments, 92, 119-168.

Rüppell, E. (1829). Abbildung und Beschreibung einiger neuer oder weniger bekannten Versteinerungen aus der Kalkschieferformation von Solnhofen (p. 12). Brönner: Frankfurt a. M.

Schäfer, W. (1962). Aktuo-Paläontologie nach Studien in der Nordsee. Frankfurt am Main: Waldemar Kramer.

Schäfer, W. (1972). Ecology and paleoecology of marine environments. Chicago: University of Chicago Press.

Schweigert, G. (1999). Erhaltung und Einbettung von Belemniten im Nusplinger Plattenkalk (Ober-Kimmeridgium, Beckeri-Zone, Schwäbische Alb). Stuttgarter Beiträge zur Naturkunde, Serie $B, 273,1-35$.

Schweigert, G., \& Dietl, G. (1999). Zur Erhaltung und Einbettung von Ammoniten im Nusplinger Plattenkalk (Oberjura, Südwestdeutschland). Stuttgarter Beiträge zur Naturkunde, Serie B, $272,1-35$

Schweigert, G., \& Dietl, G. (2001). Die Kieferelemente von Physodoceras (Ammonitina, Aspidoceratidae) im Nusplinger Plattenkalk (Oberjura, Schwäbische Alb). Berliner geowissenschaftliche Abhandlungen, E36, 131-143.

Schweigert, G., \& Dietl, G. (2008). Miscellanea aus dem Nusplinger Plattenkalk (Ober-Kimmeridgium, Schwäbische Alb). 9. Eine neue Aptychen-Formgattung. Jahresberichte und Mitteilungen des Oberrheinischen geologischen Vereins, Neue Folge, 90, $45-55$.

Schweigert, G., \& Dietl, G. (2010). The Coleoidea of the upper Kimmeridgian Nusplingen Lithographic Limestone (Upper Jurassic, SW Germany) - diversity, preservation and palaeoecology. Ferrantia, 59, 165-175.

Seilacher, A., Reif, W. E., \& Westphal, F. (1985). Sedimentological, ecological and temporal patterns of fossil Lagerstätten. Philosophical Transactions of the Royal Society London B, 311, 5-23.

Vecchione, M., Young, R. E., Donovan, D. T., \& Rodhouse, P. G. (1999). Reevaluation of coleoid cephalopod relationships based on modified arms in the Jurassic coleoid Mastigophora. Lethaia, $32,113-118$.

Viohl, G. (1994). Fish taphonomy of the Solnhofen Plattenkalk. An approach to the reconstruction of paleoenvironment. Géobios Mémoire Spéciale, 16, 81-90.

Wellnhofer, P. (1991). The illustrated encyclopedia of pterosaurs. London: Salamander.

Young, R. E., Vecchione, M., \& Donovan, D. T. (1998). The evolution of coleoid cephalopods and their present biodiversity and ecology. South African Journal of Marine Science, 20, $393-420$. 